\title{
Peningkatan Kemampuan Guru Normatif dan Adaptif dalam Menyusun Program Pembelajaran melalui Pelaksanaan In House Training
}

\author{
I Wayan Sunita \\ SMK Negeri 1 Mas Ubud \\ e-mail: sunitaiwyn@gmail.com
}

\begin{abstract}
Abstrak
Penelitian ini bertujuan untuk meningkatkan kemampuan guru Normatif dan Adaptif dalam menyusun Program Pembelajaran melalui pelaksanaan In House Training di SMK Negeri 1 Mas Ubud. Dari hasil pengamatan yang Peneliti lakukan terdapat data dan informasi bahwa dokumen program pembelajaran pada mata pelajaran Normatif dan Adaptif belum tersusun secara lengkap oleh guru sehingga menyulitkan bagi guru dalam mengadministrasikan dokumen pembelajaran dengan baik. Jika dilakukan pengecekan terhadap dokumen program pembelajaran rata-rata guru belum mempunyai dokumen pembelajaran secara lengkap. Berdasarkan kondisi tersebut Peneliti berupaya melakukan perbaikan-perbaikan terhadap kemampuan guru dalam menyusun dokumen program pembelajaran melalui pelaksanaan In House Training di sekolah. Karena dengan cara ini diyakini dapat meningkatkan kemampuan guru dalam menyusun program pembelajaran dengan lebih baik dan sistematis. Penelitian tindakan sekolah ini dilakukan di SMK Negeri 1 Mas Ubud pada bulan Juli tahun 2006 dengan obyek guru Normatif dan Guru Adaptif sebanyak 15 Orang dan pelaksanaan Penelitian Tindakan Sekolah ini dilakukan secara kolaboratif dengan partisipatif pelaksanaannya selama 2 siklus penelitian. Data hasil penelitian yang telah dikumpulkan melalui penelitian ini kemudian dianalisis menggunakan analisis deskriptif. Hasil penelitian menunjukkan adanya peningkatan kemampuan guru dalam menyusun Program Pembelajaran pada mata pelajaran Normatif dan Adaptif, setelah dilakukan In House Training di Sekolah secara terprogram. Berdasarkan data yang diperoleh dalam Penelitian Tindakan Sekolah (PTS) ini maka dapat disimpulkan bahwa penerapan In House Training dapat meningkatkan kemampuan guru Normatif dan Adaptif dalam menyusun Program Pembelajaran di SMK Negeri 1 mas Ubud tahun pelajaran 2016/2017.
\end{abstract}

Kata Kunci: Peningkatan Kemampuan Guru Normatif dan Adaptif, In House Training

\begin{abstract}
This study aims to improve the ability of Normative and Adaptive teachers in compiling Learning Programs through the implementation of In House Training at SMK Negeri 1 Mas Ubud. From the observations that the Researchers did, there were data and information that the learning program documents on Normative and Adaptive subjects had not been completely arranged by the teacher, making it difficult for the teacher to administer the learning documents properly. If you check the learning program documents, the teacher does not have a complete learning document. Based on these conditions the Researcher seeks to make improvements to the ability of the teacher in compiling learning program documents through the implementation of In House Training in schools. Because in this way it is believed to be able to improve the ability of teachers to develop learning programs better and systematically. The school action research was carried out in 1 National Vocational School in Ubud at July 206 with normative teacher and Adaptive Teachers as many as 15 people and the implementation of the School Action Research was carried out collaboratively with participatory implementation for 2 research cycles. Data from research results that have been collected through this study were then analyzed using descriptive analysis. The results of the study showed an increase in the ability of teachers to develop Learning Programs on Normative and Adaptive subjects, after being programmed In House Training in schools. Based on the data obtained in this School Action Research (PTS), it can be concluded that the implementation of In House Training can improve the ability of Normative and Adaptive teachers in compiling Learning Programs in State Vocational Schools 1 mas Ubud in the academic year 2016/2017.
\end{abstract}

Keywords: Increasing Normative and Adaptive Teacher Ability, In House Training. 


\section{Pendahuluan}

Pendidikan merupakan investasi dalam pengembangan sumber daya manusia dan dipandang sebagai kebutuhan dasar bagi masyarakat yang ingin maju. Komponen-komponen sistem pendidikan yang mencakup sumber daya manusia dapat digolongkan menjadi dua yaitu: tenaga kependidikan / guru dan non guru. Dalam Undang-Undang Nomor 20 tahun 2003 tentang Sistem Pendidikan Nasional dinyatakan bahwa, "komponen-komponen sistem pendidikan yang bersifat sumber daya manusia dapat digolongkan menjadi tenaga pendidik dan pengelola satuan pendidikan yakni (penilik, pengawas, peneliti dan pengembang pendidikan)." Tenaga gurulah yang mendapatkan perhatian lebih banyak dari pemerintah di antara komponen-komponen sistem pendidikan tersebut. Besarnya perhatian Pemerintah terhadap guru antara lain dapat dilihat dari banyaknya kebijakan khusus seperti kenaikan tunjangan fungsional guru dan sertifikasi guru.

Menurut Dharmawan (2016) kebijakan untuk meningkatkan mutu pendidikan di tingkat sekolah menengah adalah kebijakan yang sangat strategis, mengingat jenjang pendidikan menengah merupakan dasar bagi anak-anak untuk melanjutkan pendidikan ke jenjang yang lebih tinggi. Dengan demikian, meningkatkan mutu pendidikan pada jenjang menengah akan memberikan sumbangan yang sangat berarti bagi peningkatan mutu pendidikan pada jenjang yang lebih tinggi, yaitu melalui peningkatan mutu masukkannya. Menurut Lailatussaadah (2015) Guru merupakan ujung tombak yang sangat menentukan dalam sistem pendidikan secara keseluruhan, yang harus mendapatkan perhatian sentral, pertama, dan utama. Oleh karena itu, upaya perbaikan apapun yang dilakukan untuk meningkatkan kualitas pendidikan tidak akan memberikan sumbangan yang signifikan tanpa didukung oleh guru yang professional dan berkualitas. Dengan kata lain, perbaikan kualitas pendidikan harus dimulai dari guru. Menurut Osnal (2016) guru adalah tenaga fungsional yang bertugas khusus untuk mengajar, mendidik, melatih, dan menilai hasil pembelajaran peserta didik serta efektifitas mengajar guru. Tugas guru adalah profesi maka dari itu diharapkan dapat melaksanakan tugas dengan baik. Menurut Yulianti (2018) keberadaan guru amatlah penting bagi suatu bangsa, terlebih bagi keberlangsungan hidup di tengah-tengah lintasan perjalanan zaman dengan teknologi canggih dan segala perubahan serta pergeseran nilai hal ini membawa konsekuensi kepada guru untuk meningkatkan peranan dan kemampuannya. Kegiatan yang menyangkut tenaga kependidikan harus dikelola secara sistematik, efektif dan efisien. Rendahnya kualitas tenaga kependidikan akan berakibat kurangnya partisipasi dan tanggung jawab. Menurut Baharuddin (2017) mempersiapkan guru berkualitas menjadi perhatian dunia global saat ini, hal ini dikarenakan oleh paradigma dunia yang memandang pendidikan sebagai sentral pokok dalam melakukan perbaikan pada penyakit sosial masyarakat sekaligus sebagai instrumen kunci dalam memajukan perdebatan mengenai apa yang seharusnya guru tahu dan lakukan agar dapat tampil menjadi guru yang berkualitas dan efektif. Menurut Widodo (2013) dunia pendidikan perlu terus-menerus disempurnakan mutunya sesuai dengan kebutuhan masyarakat dan perkembangan iptek. Melalui dunia pendidikan akan terwujud peletakan landasan bagi pembentukan Sumber Daya Manusia (SDM) yang tangguh, yang mampu bersaing baik di tingkat regional, nasional, maupun global. Untuk mencapai sasaran tersebut, salah satu upaya yang harus dan sangat mendesak dilakukan adalah peningkatan mutu guru melalui profesionalisme guru. Guru mempunyai fungsi, peran, dan kedudukan yang sangat strategis dalam pembangunan nasional, khususnya dalam bidang pendidikan nasional.

Usaha-usaha untuk mempersiapkan guru menjadi profesional telah banyak dilakukan, namun kenyataan menunjukkan bahwa tidak semua guru memiliki kinerja yang baik dalam melaksanakan tugasnya. "Hal itu ditunjukkan dengan kenyataan seperti : (1) guru sering mengeluh kurikulum yang berubah-ubah, (2) guru sering mengeluhkan kurikulum yang syarat dengan beban, (3) seringnya siswa mengeluh dengan cara mengajar guru yang kurang menarik, (4) masih belum dapat dijaminnya kualitas pendidikan sebagai mana mestinya" (Imron, 2000:5).

Berdasarkan kenyataan tersebut dirasa begitu berat dan kompleksnya tugas serta peran guru tersebut. Untuk itu perlu diadakan pembinaan terhadap guru secara terus menerus untuk meningkatkan kinerjanya. Kinerja guru perlu ditingkatkan agar usaha dalam membimbing siswa untuk lebih giat belajar dapat berkembang. Dalam kaitannya dengan Penelitian Tindakan Sekolah ( PTS) ini Peneliti mengangkat peningkatan kemampuan guru dalam menyusun program pembelajaran untuk guru normatif dan guru adaptif di SMK Negeri 1 Mas Ubud.

Proses pengembangan kemampuan guru terbentuk dan terjadi dalam kegiatan belajar mengajar di tempat mereka bekerja. Selain itu kemampuan guru dipengaruhi oleh hasil 
pembinaan dan supervisi kepala sekolah" (Pidarta, 1992:3). Pada pelaksanaan Kurikulum 2013 menuntut kemampuan baru pada guru untuk dapat mengelola proses pembelajaran secara efektif dan efisien. Tingkat produktivitas sekolah dalam memberikan pelayananpelayanan secara efisien kepada pengguna yang kompeten (dalam hal ini peserta didik, masyarakat) akan sangat tergantung pada kualitas gurunya yang terlibat langsung dalam proses pembelajaran dan keefektifan mereka dalam melaksanakan tanggung jawab individual dan kelompok.

Direktur Jenderal Pendidikan Dasar dan Menengah bersama dengan Direktorat Pembinanya dilingkungan pendidikan Dasar dan Menengah (2008:3) menyatakan "kualitas pendidikan sangat ditentukan oleh kemampuan sekolah dalam mengelola proses pembelajaran, dan lebih khusus lagi adalah proses pembelajaran yang terjadi di kelas, sangat berpengaruh dan mempunyai andil dalam menentukan kualitas pendidikan. Konsekuensinya adalah guru harus mempersiapkan (merencanakan) segala sesuatu agar proses pembelajaran di kelas berjalan dengan efektif termasuk yang sangat penting adalah program pembelajaran".

Hal ini berarti bahwa guru sebagai fasilitator yang mengelola proses pembelajaran di kelas mempunyai andil dalam menentukan kualitas pendidikan. Konsekuensinya adalah guru harus mempersiapkan (merencanakan) segala sesuatu agar proses pembelajaran di kelas berjalan dengan efektif.

Perencanaan pembelajaran merupakan langkah yang sangat penting sebelum pelaksanaan pembelajaran. Perencanaan yang matang berupa program pembelajaran diperlukan supaya pelaksanaan pembelajaran berjalan secara efektif. Perencanaan pembelajaran dituangkan ke dalam Program Pembelajaran kemudia dijabarkan ke dalam Rencana Pelaksanaan Pembelajaran (RPP) atau beberapa istilah lain seperti desain pembelajaran, skenario pembelajaran. Program pembelajaran mencakup Tujuan Pembelajaran yang berasal dari Standar Kompetensi dan Kompetensi Dasar, (SK dan KD), Hasil Belajar yang ingin dicapai, berdasarkan dengan tujuan yang telah ditentukan dengan ditunjang oleh struktur pembelajaran dalam kurikulum, aktivitas pembelajaran, metoda yang digunakan dan strategi pembelajaran yang dilaksanakan, sarana dan prasarana yang menunjang, sumber daya yang menunjang, alat dan bahan, sumber belajar (buku, modul, dan bahan ajar yang sesuai), serta media yang akan digunakan dalam kegiatan pembelajaran. Sedangkan RPP memuat KI, KD, indikator yang akan dicapai, materi yang akan dipelajari, langkah pembelajaran, media pembelajaran, dan sumber belajar serta penilaian. Guru harus mampu berperan sebagai desainer (perencana), implementor (pelaksana), dan evaluator (penilai) kegiatan pembelajaran. Guru merupakan faktor yang paling dominan karena di tangan gurulah keberhasilan pembelajaran dapat dicapai. Kualitas mengajar guru secara langsung maupun tidak langsung dapat mempengaruhi kualitas pembelajaran pada umumnya. Seorang guru dikatakan profesional apabila: (1) serius melaksanakan tugas profesinya, (2) bangga dengan tugas profesinya, (3) selalu menjaga dan berupaya meningkatkan kompetensinya dalam melaksanakan pembelajaran, (4) bekerja dengan sungguh tanpa harus diawasi, (5) menjaga nama baik profesinya, (6) bersyukur atas imbalan yang diperoleh dari profesinya, (7) mampu membuat administrasi pembelajaran dengan baik dan sesuai struktur pembelajaran.

Peraturan Pemerintah Nomor 19 Tahun 2005 tentang 8 Standar Nasional Pendidikan menyatakan standar proses merupakan salah satu SNP untuk satuan pendidikan Dasar dan Menengah yang mencakup: 1) Perencanaan proses pembelajaran, 2) Pelaksanaan proses pembelajaran, 3) Penilaian hasil pembelajaran, 4) dan pengawasan proses pembelajaran. Perencanaan Program pembelajaran meliputi Silabus dan Rencana Pelaksanaan Pembelajaran (RPP). Program Pembelajaran, Silabus dan RPP dikembangkan oleh guru pada satuan pendidikan. Guru pada satuan pendidikan berkewajiban menyusun Program pembelajaran, Silabus dan RPP secara lengkap dan sistematis agar pembelajaran berlangsung secara interaktif, inspiratif, menyenangkan, menantang, memotivasi peserta didik untuk berpartisipasi aktif, serta memberikan ruang yang cukup bagi prakarsa, kreativitas, dan kemandirian sesuai dengan bakat, minat dan perkembangan fisik serta psikologis peserta didik. Semua dokumen tersebut merupakan satu kesatuan yang tidak dipisahkan untuk mendukung kelancaran pelaksanaan kegiatan Belajar Mengajar. Menurut Jayadipura (2018) Merencanakan proses pembelajaran yang meliputi kegiatan mengkaji kurikulum, menyusun silabus, strategi pembelajaran, sumber belajar dan satuan kegiatan pembelajaran sebenarnya merupakan hal terpenting, karena perencanaan itu merupakan landasan dari pelaksanaan yang akan dilakukan. Namun hal ini dianggap tidak terlalu penting karena banyak guru yang menganggap bahwa kepemilikan RPP dapat dilakukan dengan mencontoh dokumen-dokumen yang disusun sekolah lain. Sehingga berdampak pada banyaknya RPP yang tidak sesuai 
dengan kebutuhan di sekolah masing-masing. Dalam hal ini penulis melakukan pengkajian terhadap penilaian kemampuan guru dalam menyusun program pembelajaran melalui pelaksanaan In House Training. Menurut Ervanti Ayuningtyas (2017) In House Training (IHT) merupakan program yang diselenggarakan di sekolah atau tempat lain menggunakan peralatan dan materi yang relevan dengan permasalahan yang dihadapi, tujuannya adalah untuk mengembangkan kompetensi berupa skill, knowledge, dan atittude.

Masalah yang terjadi di lapangan masih ditemukan adanya guru (SMK Negeri 1 Mas Ubud) yang belum dapat menunjukkan program Pembelajaran yang dibuat secara lengkap dan tersusun dengan sistematis sesuai kaidah penyusunan program pembelajaran yang telah ditentukan. Melihat kondisi demikian mendorong Peneliti untuk melakukan perbaikanperbaikan untuk meningkatkan kualitas pembelajaran pada mata pelajaran normatif dan adaptif di SMK Negeri 1 Mas Ubud.

Dengan keadaan demikian, peneliti sebagai pembina sekolah berusaha untuk memberikan bimbingan dan pendampingan kepada guru dalam menyusun Program Pembelajaran. Sehubungan dengan hal tersebut diatas maka dalam Penelitian Tindakan Sekolah (PTS) Peneliti mengambil judul: Peningkatan Kemampuan Guru Normatif dan Adaptif dalam menyusun Program Pembelajaran Melalui Pelaksanaan In house Training SMK Negeri 1 mas Ubud tahun Pelajaran 2016/2017.

\section{Metode}

Penelitian ini adalah Penelitian Tindakan Sekolah sehingga dalam pelaksanaannya menekankan pada peningkatan kemampuan guru normatif dan adaptif dalam menyusun program pembelajaran, SMK Negeri 1 Mas Ubud. Penelitian ini dilakukan di Kelas SMK Negeri 1 Mas ubud. Subjek penelitian sebanyak 15 guru mata pelajaran normatif dan adaptif.

Waktu Penelitian mulai dari Perencanaan sampai dengan penulisan laporan hasil penelitian tersebut mulai dari bulan Juli s.d Oktober 2016, tahun pelajaran 2016/2017. Waktu pelaksanaan Penelitian Tindakan Sekolah ini menyesuaikan dengan kalender pendidikan di SMK Negeri 1 Mas Ubud.

Variabel pada penelitian ini yakni: (1) variabel input yang terkait dengan, guru, bahan pelajaran, sumber belajar, prosedur evaluasi, lingkungan belajar, dan lain sebagainya; (2) variabel proses pelanggaran KBM seperti interaksi belajar-mengajar, keterampilan bertanya, guru, gaya mengajar guru, cara membimbing siswa dalam belajar, implementasi berbagai metode mengajar di kelas, dan sebagainya, dan (3) variabel output seperti rasa keingintahuan siswa dapat tercipta berkat bimbingan guru dalam mengajar, kemampuan siswa mengaplikasikan pengetahuan, motivasi siswa, hasil belajar siswa, sikap terhadap pengalaman belajar yang telah digelar melalui tindakan perbaikan, semua ini bersumber pada program pembelajaran yang dirancang oleh guru. 
Kegiatan setiap siklus pada penelitian ini digambarkan pada gambar di bawah ini:

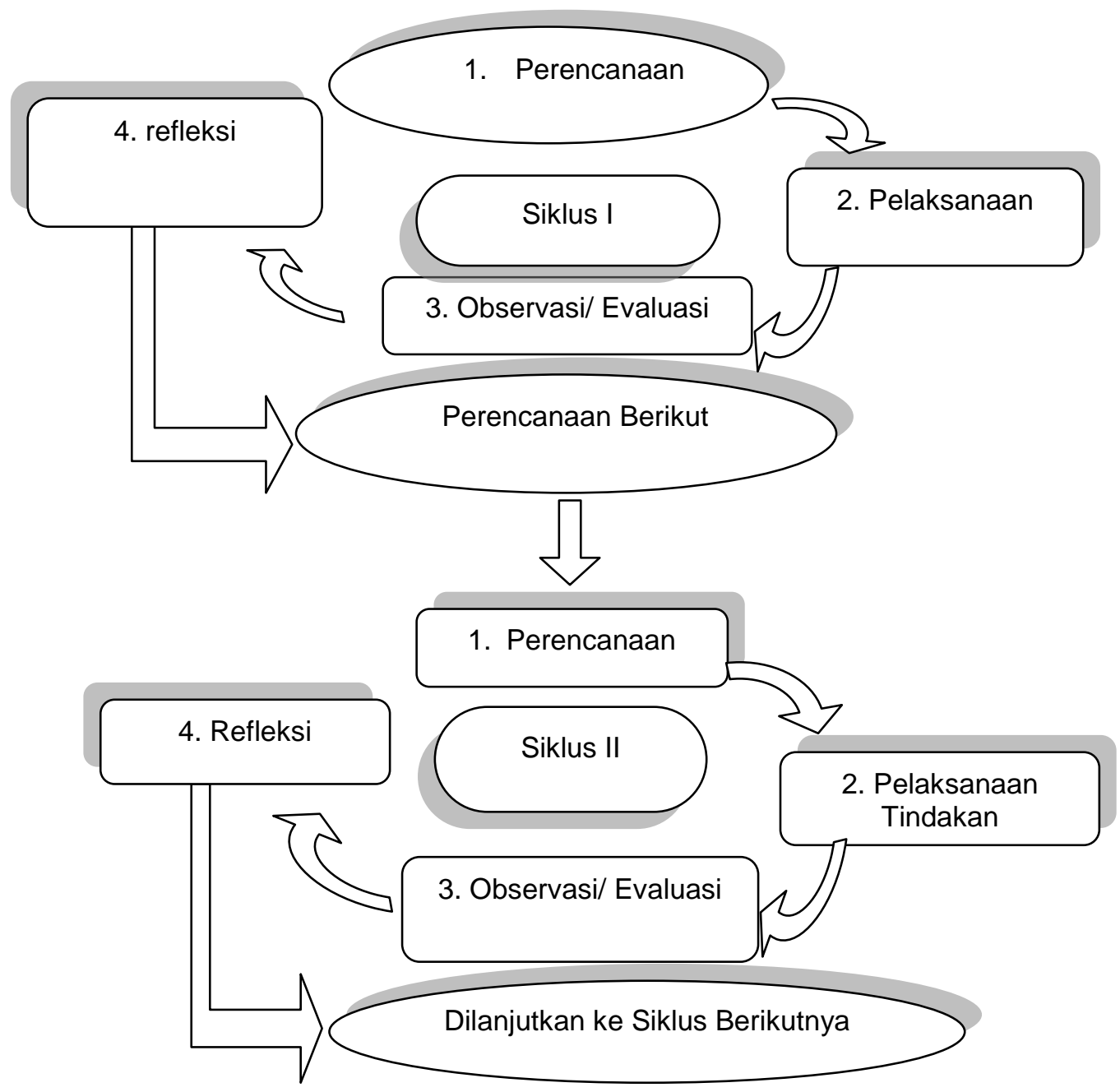

Gambar 1. Model Siklus Penelitian Tindakan Sekolah

Penjelasan dari gambar diatas bahwa kegiatan yang dilakukan pada setiap siklus dan setiap tahapan adalah sebagai berikut:

Siklus I

a. Perencanaan

Beberapa kegiatan yang dilakukan oleh guru pada tahap perencanaan, yaitu:

1)Menyusun Program Pembelajaran dan termasuk penyusunan Rencana pelaksanaan Pembelajaran (RPP) dengan pendekatan pembelajaran atau metoda yang telah ditetapkan.

2)Menyusun kisi-kisi dan instrumen penelitian berupa tes kemampuan awal serta instrumen postes siklus I

3)Menyusun lembar observasi kegiatan guru dan hasil penyusunan program pembelajaran

b. Pelaksanaan

1)Melaksanakan tes awal (pre test), sebelum dilakukan In house Training penyusunan program pembelajaran.

2)Melaksanakan kegiatan In House Training dan sekaligus melakukan pengamatan terhadap hasil kerja guru yakni program pembelajaran dan melihat aktivitas mengajar.

3)Melihat hasil seberapa besar peningkatan kemampuan guru yang dicapai setelah dilakukan In House Training penyusunan program Pembelajaran

4)Melaksanakan tes akhir siklus I

c. Observasi

Untuk bisa mendapatkan sejumlah informasi yang akan digunakan sebagai bahan evaluasi dan refleksi maka selama pelaksanaan pembelajaran juga dilakukan 
pengamatan (observasi) terhadap aktivitas guru dalam menyusun program pembelajaran dan menerapkannya dalam kegiatan belajar mengajar.

d. Refleksi

Catatan yang diperoleh dari hasil observasi selanjutnya dianalisis. Begitu juga dengan data hasil tes akhir siklus I. Kelemahan-kelemahan yang ditemukan pada proses pelaksanaan siklus I dikumpulkan untuk kemudian diperbaiki sehingga siklus II bisa lebih baik.

Siklus II

a. Perencanaan

Hasil refleksi pada siklus I dijadikan dasar untuk melaksanakan perbaikan pelaksanaan siklus II. Oleh karena itu, kegiatan yang akan dilakukan pada perencanaan siklus II merupakan perbaikan-perbaikan dari kelemahan yang ditemukan sebelumnya. Perbaikan yang dilakukan adalah sebagai berikut:

1)Memeriksa program pembelajaran termasuk Rencana pelaksanaan Pembelajaran (RPP) dengan pendekatan atau metoda yang dilaksanakan untuk siklus II

2)Memeriksa kisi-kisi dan instrumen penelitian berupa soal postest siklus II

3)Memeriksa lembar observasi kegiatan guru

4)Memeriksa bahan ajar (materi ajar), yang telah disusun oleh guru

b. Pelaksanaan

1)Melaksanakan tes awal (pretest)

2)Guru melaksanakan pembelajaran sesuai dengan Program pembelajaran serta RPP yang telas disusun.

3)Melaksanakan tes akhir (postest) siklus II

c. Observasi

Untuk bisa mendapatkan sejumlah informasi yang akan digunakan sebagai bahan evaluasi dan refleksi maka selama pelaksanaan pembelajaran juga dilakukan pengamatan (observasi) terhadap aktivitas siswa serta interaksi yang terjadi antara siswa dengan siswa, siswa dengan media yang digunakan, serta siswa dengan guru.

d. Refleksi

Catatan yang diperoleh dari hasil observasi selanjutnya dianalisis. Begitu juga dengan data hasil tes akhir siklus II. Kelemahan-kelemahan yang ditemukan pada proses pelaksanaan siklus II dikumpulkan untuk kemudian diperbaiki sehingga siklus pada siklus II tercipta suasana pembelajaran lebih baik.

Pada siklus II diharapkan guru mampu meningkatkan kemampuannya dalam menyusun program pembelajaran sesuai dengan yang telah dilatihkan dalam kegiatan In House Training. Indikator ketuntasan pada penelitian ini adalah: terdapat peningkatan mutu KBM mata pelajaran normnatif dan adaptif. Dimana nantinya akan berdampak pada peningkatan kemampuan guru dalam menyusun program pembelajaran untuk meningkatkan mutu KBM di SMK Negeri 1 Mas Ubud untuk mata pelajaran normatif dan adaptif. Hasil akhir yang diperoleh adalah meningkatnya kualitas tamatan siswa SMK Negeri 1 Mas Ubud.

\section{Hasil dan Pembahasan}

Penelitian Tindakan Sekolah melalui pelaksanaan In House Training (IHT) ini bermula dari permasalahan kelengkapan dokumen pembelajaran guru normatif dan adaptif di SMK Negeri 1 Mas Ubud terlihat oleh Peneliti belum lengkap dan belum mengacu pada petunjuk penyusunan Program Pembelajaran atau SOP. Salah satu penyebab adalah kemampuan guru dalam menyusun program pembelajaran masih belum memadai. Kepala sekolah memutuskan bahwa tindakan pemecahan masalah yang dilakukan adalah dengan melaksanakan Penelitian Tindakan Sekolah (PTS).

Hasil yang dicapai selama Penelitian Tindakan Sekolah dari prasiklus, siklus I dan siklus II dapat di paparkan dalam pembahasan sebagai berikut:

1. Prasiklus

a. Sebanyak 4 orang guru yang mencapai ketuntasan dalam menyusun program pembelajaran

b. Sebanyak 11 orang guru yang belum mencapai ketuntasan dalam menyusun program pembelajaran

c. Jumlah rata-rata nilai 39

d. Ketuntasan mencapai $26,66 \%$ 
e. Guru yang belum tuntas mencapai $73,34 \%$

f. Guru belum paham dalam menyusun program pembelajaran yang benar

g. Selama ini guru kurang proaktif dalam mencari tahu tentang bagaimana menyusun program pembelajaran yang baik dan benar

h. Kondisi riil ini berdampak terhadap kurang sempurnanya pelaksanaan Kegiatan Belajar Mengajar dalam pembelajaran mata pelajaran normatif dan adaptif

i. Melihat kondisi demikian dilakukan perbaikan-perbaikan di siklus berikutnya melalui pelaksanaan In House Training $(I H T)$

2. Siklus I

a. Sebanyak 14 orang guru yang telah mencapai ketuntasan dalam menyusun program pembelajaran

b. Sebanyak 1 orang guru yang belum mencapai ketuntasan dalam menyusun program pembelajaran

c. Jumlah rata-rata nilai adalah 43,53

d. Ketuntasan mencapai $93,33 \%$

e. Guru yang belum mencapai ketuntasan mencapai $6,7 \%$

f. Pada siklus I telah terjadi peningkatan kemampuan guru dalam menyusun program pembelajaran untuk mata pelajaran normatif dan adaptif

g. Pada siklus I masih ada 1 orang guru yang belum dapat menuntaskan tugasnya dalam menyusun program pembelajaran meskipun telah di lakukan bimbingan melalui In House Training. kesulitan yang mendasar adalah dalam mengemas materi pelajaran yang mampu memdorong siswa kreatif dan inovatif.

h. Pelaksanaan fasilitasi terhadap guru normatrif dan adaptif melalui In House Training dilaksanakan di siklus I.

i. Untuk mencapai peningkatan kemampuan guru dalam menyusun program pembelajaran keaktifan guru dalam mencari sumber belajar dan menuangkannya dalam program pembelajaran dilakukan melalui bimbingan.

3. Siklus II

a. Sebanyak 15 orang guru yang telah mencapai ketuntasan dalam menyusun program pembelajaran

b. Sebanyak 15 orang guru normatif dan adaptif yang di observasi dalam Penelitian Tindakan Sekolah ini telah mampu menunjukkan hasil dengan baik sesuai dengan tujuan yang ingin dicapai dalam Penelitian Tindakan Sekolah ini.

c. Nilai rata-rata yang dicapai pada siklus II adalah $46,4 \%$ suatu peningkatan yang dicapai guru pada sikjlus II

d. Ketuntasan dalam melaksanakan tugas penyusunan Program Pembelajaran telah dicapai $100 \%$ pada siklus II

e. Pelaksanaan In House Training untuk meningkatkan kemampuan guru normatif dan adaptif terbukti dan berhasil meningkatkan kemampuan guru dengan baik. Melalui In House Training guru memperoleh pengalaman pelatihan secara efektif di sekolah tempat mengajar dan dilaksanakan berdasarkan kebutuhan riil guru serta pihak sekolah.

Keseluruhan hasil yang telah dicapai dalam Penelitian Tindakan Sekolah ini dapat disajikan dalam Tabel dibawah ini:

Tabel 1. Rekapitulasi Hasil Penelitian Tindakan Sekolah

\begin{tabular}{|c|c|c|c|c|c|}
\hline \multirow{2}{*}{ No } & \multirow[b]{2}{*}{ Kriteria } & \multicolumn{3}{|c|}{ Jenis Tindakan } & \multirow[b]{2}{*}{ Ket. } \\
\hline & & $\begin{array}{l}\text { Pre test/ } \\
\text { Prasiklus }\end{array}$ & S.I & S.II & \\
\hline 1. & Jumlah Nilai & 585 & 653 & 696 & Meningkat \\
\hline 2. & Rata-rata Nilai & 39 & 43,53 & 46,4 & Meningkat \\
\hline 3. & $\begin{array}{l}\text { Ketuntasan } \\
\text { dicapai guru }\end{array}$ & $26,66 \%$ & $93,33 \%$ & $100 \%$ & Meningkat \\
\hline 4 & Guru Yg Blm Tuntas & $73,34 \%$ & $6,7 \%$ & $0 \%$ & - \\
\hline
\end{tabular}

Hasil penelitian ini sejalan dengan hasil penelitian yang dilakukan oleh Corinita (2016) yang berjudul Pelaksanaan In House Training untuk Meningkatkan Kompetensi Guru dalam Menyusun RPP di Sekolah Menengah Pertama. Pada penelitiannya dinyatakan bahwa: pelaksanaan In House Training dapat meningkatkan kompetensi guru di dalam menyusun 
rencana pelaksanaan pembelajaran di SMP Negeri 32 Pekan Baru tahun pelajaran 2015/2016. Pada siklus I kompetensi guru di dalam menyusun RPP adalah 71.3 dengan $50 \%$ guru yang telah dapat menyusun RPP dengan baik dan benar. Pada siklus II kompetensi guru di dalam menyusun RPP adalah 87.8 dengan 100\% guru yang telah dapat menyusun RPP dengan baik dan benar.

\section{Kesimpulan}

Berdasarkan hasil Penelitian Tinadakan Sekolah (PTS) dapat disimpulkan sebagai berikut: 1) Pelaksanan In House Training (IHT) jika dilaksanakan secara konsisten dapat meningkatkan kemampuan guru SMK Negeri 1 Mas Ubud dalam menyusun Program Pembelajaran dengan lengkap sesuai dengan pedoman dan SOP yang ada, 2) Guru menunjukkan keseriusan dalam memahami dan menyusun Program pembelajaran mata pelajaran normatif dan adaptif dan setelah mendapatkan pencerahan melalui kegiatan In House Tarining $(I H T)$ dalam penyusunan program pembelajaran mata pelajaran normatif dan adaptif, dan 3) Berdasarkan hasil wawancara dan observasi yang dilakukan oleh Peneliti bahwa dengan dilaksanakannya program In House Training di sekolah guru memperoleh pengetahuan yang sangat berharga dan mampu membuka wawasan guru SMK Negeri 1 Mas Ubud khususnya guru mata pelajaran normatif dan adaptif, sehingga dapat meningkatkan kemampuan guru dalam menyusun Program Pembelajaran.

Dengan pelaksanaan program In House Training (IHT) secara konsisten dapat meningkatkan motivasi dan kompetensi guru dalam menyusun dokumen pembelajaran dengan benar. Oleh karena itu, peneliti menyampaikan beberapa saran sebagai berikut:

1. Semangat dan motivasi guru yang sudah tertanam dalam penyusunan program pembelajaran hendaknya terus dipertahankan dan ditingkatkan / dikembangkan, untuk meningkatkan mutu pembelajaran di SMK Negeri 1 Mas Ubud.

2. Program pembelajaran yang disusun / dibuat hendaknya mengandung komponen-komponen secara lengkap dan baik karena program pembelajaran merupakan acuan / pedoman dalam melaksanakan pembelajaran.

3. Program pembelajaran yang telah disusun hendaknya di kemas menjadi satu naskah dokumen pembelajaran dan dibuat rangkap untuk di administrasikan agar lebih mudah dalam pengelolaan administrasi sekolah serta mencarinya bila diperlukan.

4. Penerapan program In House Training telah terbukti mampu meningkatkan kemampuan guru dalam menyusun program pembelajaran. Hendaknya program In House Training dapat di terapkan secara rutin untuk meningkatkan untuk meningkatkan kualitas personil (Guru dan pegawai) di SMK Negerei 1 Mas Ubud.

5. Kepada para pembaca yang ingin melakukan Penelitian Tindakan Kelas (PTK) atau Penelitian Tindakan Sekolah (PTS), disarankan agar dalam melakukan tindakan dan refleksi dapat dilaksanakan secara mendalam dan fokus terhadap kelemahan-kelemahan yang terjadi, untuk memperoleh hasil yang baik sesuai dengan tujuan yang ingin dicapai.

\section{Daftar Pustaka}

Baharuddin, Rabial Kanada. 2017. Pengembanganprofesionalisme Guru Melalui In House Training. Journal of Islamic Education Management Vol. 3 No. 2 Hal. 1-20. http://jurnal.radenfatah.ac.id/index.php/El-idare. Diakses 17 Mei 2019.

Corinorita. 2016. Pelaksanaan In House Training untuk Meningkatkan Kompetensi Guru dalam Menyusun RPP di Sekolah Menengah Pertama. Jurnal Ilmu Pendidikan Sosial, Sains, dan Humaniora Vol. 3 No. 1, Maret 2017.

Dharmawan, K., dkk. 2016. Model Pembinaan 'In-House Training' Sebagai Upaya untuk Meningkatkan Kemampuan Guru dalam Penelitian dan Penulisan Karya IImiah. Jurnal Udayana Mengabdi Volume 15 Nomor 2. https://ojs.unud.ac.id/index.php. Diakses 17 Mei 2019.

Direktorat Pembinaan Sekolah Menengah Atas. 2008. Panduan Pengembangan Bahan Ajar. Jakarta: Departemen Pendidikan Nasional. 
Ervanti Ayuningtyas, Aih. 2017. Evaluasi Program Pelatihan In House Training (IHT) di Sekolah Dasar Swasta. Jurnal Manajemen Pendidikan Vol. 4 No. 2 Hal. 171-183. https://www.researchgate.net/. Diakses 17 Mei 2019.

Imron, Ali. 2000. Belajar dan Pembelajaran. Jakarta: Pustaka Jaya.

Jayadipura, Yadi. 2018. In House Training untuk Meningkatkan Kemampuan Guru dalam Menyusun RPP. Jurnal Idaarah Vol. II No. 2. http://journal.uinalauddin.ac.id/index.php/idaarah/article/download/260-268/pdf. Diakses 17 Mei 2019.

Lailatussaadah. 2015. Upaya Peningkatan Kinerja Guru. Intelektualita-Volume 3, Nomor 1 Hal 17-25. https://media.neliti.com/. Diakses 17 Mei 2019.

Osnal, dkk. 2016. Meningkatkan Kemampuan Guru dalam Menyusun Tes Hasil Belajar Akhir Semester Melalui Workshop di KKG Gugus 02 Kecamatan Sumbermalang Tahun 2014/2015. Pancaran Vol. 5 No. 1 Hal 67-82. https://jurnal.unej.ac.id/index.php/ . Diakses 17 Mei 2019.

Peraturan Pemerintah Nomor 19 Tahun 2005 tentang 8 Standar Nasional Pendidikan.

Pidarta, Made. 1992. Pemikiran Tentang Supervisi Pendidikan. Jakarta: Bina Aksara.

Undang-Undang Nomor 20 tahun 2003 tentang Sistem Pendidikan Nasional.

Widodo, Suwarno, dkk. 2013. Peningkatan Kompetensi Guru Profesional Berbasis Penulisan Artikel Hasil PTK Bagi Guru Anggota PGRI di Kabupaten Purworejo. Jurnal Penelitian Pendidikan dan Pengajaran Wawasan Pendidikan Vol. 1 No. 1. https://media.neliti.com/media/publications/. Diakses 17 Mei 2019.

Yulianti, Fuzi. 2018. Peningkatan Keterampilan Guru Membuat Powerpoint melalui In House Training di SD Negeri Pabuaran. Jurnal Penelitian Kebijakan Pendidikan Volume 11 Nomor 3. http://jurnalpuslitjakdikbud.kemdikbud.go.id/index.php. Diakses 17 Mei 2019. 